\title{
Jejak Singkat Wajah Perkembangan Kota: Pasar, Persekolahan, Perkantoran Dan Monumen Di Kota Ambon Pada Masa Kolonial Belanda
}

\section{Andrew Huwae*}

\section{Abstraksi}

Study concerning growth of history a town progressively draw to continue to be checked. This matter it is of course is not quit of historical fact which accompany grow its flower a town, which in course of him sometime can meet the existence of separate unique, where unique that's which have differentiated among town which is one with town which is another palce in Ambon.City as which is depicted in this writing also have unique such as those which meant. Unique in the meaning that on the way history, town of Ambon do not only started woke up of a fortress, but because on the way this town history have been differentiated by appearance of heterogenitas society and culture, or also by education and infrastructure education

\section{Pendahuluan}

Sebagai kota kolonial yang dirintis oleh Portugis dan VOC, kota Ambon berkembang sebagai kota pemerintahan dan perdagangan. Pada tahun 1605 , VOC membentuk administrasi pemerintahan yaitu "Gouvernemen Van Amboina", meliputi wilayah yang pernah dibawah kekuasaan Portugis di Pulau Ambon dan Kepulauan Lease dengan berkedudukan di Kota Ambon. Tahun 1866, Gouvernement der Molukken

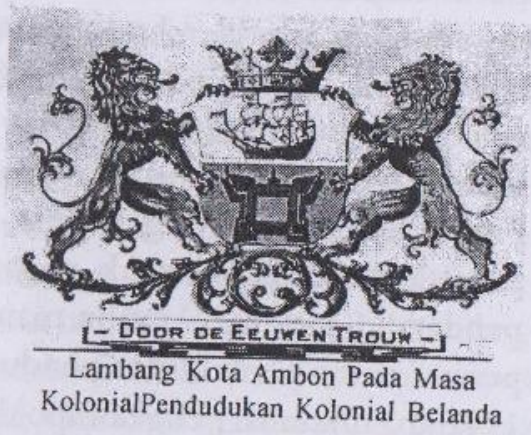
dihapus dan dibentuk dua keresidenan, yaitu Keresidenan Ternate dan Keresidenan Ambon. Keresidenan Ambon meliputi wilayah Ambon dan Banda, dengan pusat keresidenan di Kota Ambon. Keadaan ini 
dipertahankan dalam reorganisasi pada tahun 1925 ketika kedua keresidenan tersebut digabungkan kembali menjadi "Gouvernement der Molukken" yang berkedudukan di Kota Ambon. Pusat pemerintahan berada di benteng "Kota Laba" yang oleh pemerintah Belanda disebut sebagai benteng "Nieuw Victoria". Sebagai pusat pemerintahan Hindia Belanda atau kota kolonial, kota Ambon juga merupakan pusat administrasi yang mencakup suatu masyarakat yang terdiri atas negerinegeri yang masing-masing berdiri sendiri atau berstatus otonom (Pattikayhatu J. A, 1993).

Kota Ambon juga merupakan kota perdagangan, terutama pada abad ke-17 sampai abad ke-19. sebagai pusat perdagangan yang dibangun VOC sejak tahun 1619, kota Ambon merupakan salah satu mata rantai dari suatu sistem perdagangan nusantara yang berpusat di Batavia, yang secara hierarki merupakan mata rantai internasional yang berpusat di Amsterdam. Komuditi perdagangan adalah cengkeh, karena Kota Ambon berfungsi sebagai pusat pengumpulan cengkih dari Pulau Ambon, Kepulauan Lease dan pulau-pulau lain di Maluku Tengah. Sehubungan dengan ini Kota Ambon merupakan bagian integral dari sistem pertanian di pedesaan (negeri-negeri) yang rakyatnya diharuskan mengusahakan perkebunan cengkih, terkait dengan monopoli perdagangan cengkih yang dilakukan Belanda (Leirissa R. Z, 1983).

Dari masa VOC sampai abad ke-20, batas-batas alamiah Kota Ambon adalah Sungai Wai Batu Merah di sebelah timur dan Sungai Wai Batu Gajah di sebelah barat. Sedangkan batas selatan adalah kaki pegunungan Soya dan batas utara adalah laut Teluk Ambon. Luas wilayah Kota Ambon adalah 4,02 $\mathrm{Km}^{2}$ (Staatsblad No. 91 tahun 1888)

Sehubungan dengan fungsi Kota Ambon sebagai kota pemerintahan dan perdagangan, maka di Kota Ambon telah terdapat prasarana pendukung seperti jalan, pasar, pelabuhan, kantor dan pemukiman, baik untuk pegawai pemerintah Belanda, masyarakat pendatang dari luar Ambon maupun penduduk asli. Saat itu mulai terjadi percampuran pemukiman penduduk, sehingga pada pertengahan abad ke19 jarang dijumpai pengelompokkan pemukiman penduduk menurut warga negara atau asal-usul. Sesuai fungsi kota sebagai kota pemerintahan dan perdagangan, maka kawasan benteng Nieuw Victoria, pelabuhan laut dan pertokoan yang letaknya berdekatan di pantai Honipopu merupakan kawasan pusat kegiatan masyarakat, sedangkan perkantoran dan fasilitas sosial tumbuh di sepanjang jalan-jalan utama (Leirissa R. Z, et al, 2004).

Pembangunan fisik kota yang dirintis pada zaman pendudukan Portugis dilanjutkan pada zaman VOC, terutama pemukiman dan jalanjalan utama kota. Pada awal abad ke-20 sesuai dengan "politik etika", terjadi beberapa perubahan yang mendasar pada kondisi sosial dan fisik Kota Ambon. Sampai tahun 1930 telah dibuka sekolah-sekolah pemerintahan dan sekolah-sekolah swasta. Untuk menjalankan desentralisasi, pada tahun 1921 dibentuk "Ambonraad" (Dewan Kota) dan "Gemeenteraad" (Dewan Kota Praja). Pembangunan fisik kota ditingkatkan sesuai dengan penetapan-penetapan yang yang dibuat oleh Gemeente raad dan dilaksanakan oleh pemerintah kota. Kota Ambon diperluas menjadi enam wijk (semacam rayon wilayah administrasi) dan perbaikan kampungkampung seperti Halong, Soya Kecil, Tanah Tinggi, Valentijn, Pohon Puleh, Hatiwe dan Waihaong. Juga perbaikan semua jalan-jalan di pusat kota dan pembangunan jalan baru yang menghubungkan Kota Ambon dan negeri-negeri di sekitar Pulau Ambon. Beberapa prasarana penting lainnya dibenahi pula seperti penerangan (listrik) dan air bersih (air minum) serta tempat-tempat lainnya.

\section{A. Pasar}

Sebuah bangunan megah yang didirikan pada masa pemerintahan VOC di Kota Ambon adalah "pasar" pada tahun 1690, terletak di tepi pantai ke arah barat benteng Victoria. Pembangunannya diprakarsai oleh Gouverneur van Amboina yang memerintah saat itu, yakni Gubernur Dirk de Haas (1687-1691), ukurannya jauh lebih besar dari gedung-gedung gereja yang berada di Kota Ambon. Valentijn mengatakan, bahwa ia belum pernah melihat sebuah pasar yang sedemikian indah dengan letaknya yang begitu bagus sehingga orang bisa menikmati pemandangan teluk dan dermaga yang memanjang dari gerbang laut benteng Victoria. Bahkan bagi Valentijn, pasar ini adalah gedung terindah di Kota Ambon pada masa itu. Bangunan pasar ini tidak bertembok, dan atap gentengnya ditopang oleh sejumlah pilar. Di tempat inilah para wanita dari negeri-negeri Leitimor datang berjualan sayuran, daging, buah, sagu dan sebagainya untuk dibeli 
warga. Tetapi bangunan pasar yang megah ini kemudian hancur akibat gempa bumi yang melanda Kota Ambon pada tahun 1754

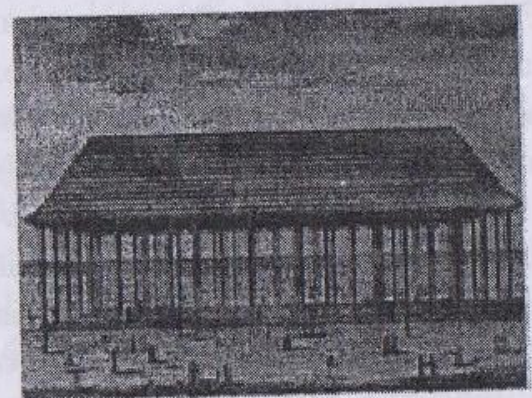

Sesudah kejadian tersebut, bangunan pasar dibangun kembali, namun tidak menyerupai bentuk aslinya atau tidak semegah bangunan pasar sebelumnya. Tetapi kemudian pada tahun 1898, terjadi lagi gempa bumi yang melanda Kota Ambon. Walaupun gempa bumi kali ini tidak sekuat gempa yang terjadi sebelumnya, namun gempa tersebut mengakibatkan bangunan pasar mengalami sedikit kerusakan.

Bangunan pasar tersebut kembali dibangun dan diperbaiki sesudah gempa bumi yang melanda Kota Ambon pada akhir abad ke-19. Bangunan pasar ini telah dibuat dalam bentuk yang lebih permanen. Bentuk dari bangunan pasar ini tidak bertembok, telah memakai senk dan ditopang oleh beberapa tiang penyangga, sehingga tampak seperti pasar terbuka. Bangunan ini dibuat lebih baik lagi untuk mempermudah warga yang

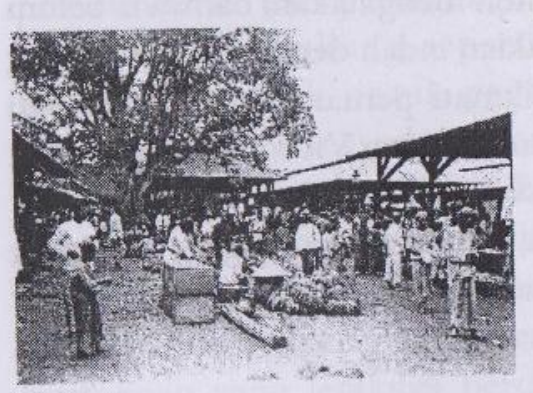
hendak membeli dan berjualan di pasar, karena bangunan pasar tersebut tidak hanya terdiri dari satu bangunan, seperti bangunan pasar sebelumnya yang dibangun pada tahun 1690. Bangunan pasar pada masa ini lebih unik dari bangunan pasar sebelumnya dan dari bentuk bangunan pasar di Kota Ambon kini. Dikatakan unik, karena bangunan pasar dibangun kembali berdasarkan pengelompokkan dari fungsi penjualannya masing-masing, sehingga proses pembelian dan penjualan lebih mudah dan teratur. Bentuk pasar tersebut terdiri dari beberapa bangunan, karena telah dikelompokkan berdasarkan isi dan fungsinya (seperti yang terlihat pada gambar). Sehingga ada bangunan pasar yang khusus berjualan buah, sayuran, sagu, daging, kayu bakar, dan sebagainya.

\section{B. Persekolahan}

Seperti kita ketahui, bahwa Sistem pendidikan di Maluku Tengah sesungguhnya sudah ada sejak masa VOC. Untuk itu, selain gedung-gedung pemerintah seperti tersebut diatas, juga terdapat bangunan-bangunan sekolah milik pemerintah Belanda yang terdapat di kota Ambon. Pembangunan Sekolah Hindia Belanda berawal dari Politik Etika pemerintah Belanda yang dicanangkan pada tahun 1901 untuk menggantikan "Ambonsche Burger School" (sekolah orang Ambon) yang dibentuk tahun 1856. Ambonsche Burger School (ABS) menggunakan bahasa Belanda sebagai bahasa pengantar, walau dalam tahun pertama masih digunakan bahasa melayu. Para murid tidak dipungut bayaran sehingga mereka yang tidak sanggup pun bisa bersekolah, karena ABS ditunjang oleh pemerintah dengan subsidi. Melalui sekolah itulah kalangan "Ambonsche Burger" (orang Ambon yang menjadi warga kota Ambon) menyerap kebudayaan kebudayaan barat, sehingga tercipta jarak sosial antara mereka dengan penduduk negeri yang ada di sekelilingnya.

Namun tidak semua pihak mendukung sepenuhnya pendidikan berbasis bahasa Belanda itu. Dua alasan utama dikemukakan untuk menunjang pendapat itu. Pertama sekolah berbahasa Belanda itu terlalu mewah bagi anak-anak dari keluarga-keluarga pribumi yang menjadi warga kota ("Inlander Burger") yang dari sudut ekonomi tidak berbeda dengan dengan "Inlander" pada umumnya. Kedua, mutu sekolah itu terlalu rendah untuk menjamin para lulusannya untuk menjadi "ambtenaar" (pegawai negeri) atau guru. Sejalan dengan Politik Etika pemerintah Belanda, sistem pendidikan di Maluku Tengah sudah sangat diperluas. Pertama-tama ABS diubah menjadi HIS ("Hollandsch Inlandche School"). Kemudian baik pemerintah maupun pihak swasta mulai mendirikan sekolah-sekolah dengan kurikulum baru. 

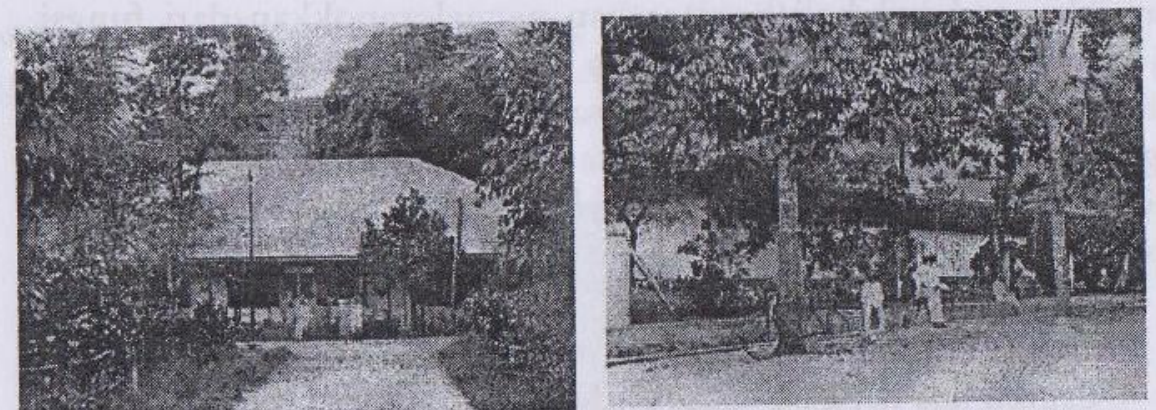

Hollandsch Inlandche School yang terletak di Batu Gantong dan Mardika tahun 1925.

Sampai tahun 1930 di Kota Ambon telah terdapat sepuluh buah sekolah milik pemerintah, yaitu tiga buah ELS ("Europeesche Lagere School"), sekolah dasar berbahasa Belanda untuk orang Belanda dan tiga buah HIS (sekolah dasar berbahasa Belanda bagi inlanders). Salah satunya berada di jalan "de Weg van Nusaniwe", tepatnya di kompleks sekolah Kristen Urimessing sekarang dan dua buah lainnya terletak di Mardika dan Batu Gantong; dua buah "Tweedeschool" (sekolah dasar berbahasa Melayu); satu buah MULO (sekolah menengah pertama) yang terletak di "Paradijsstraat", kini bernama jalan Dr. Setia Budi, tepatnya berada di kompleks SMP Negeri 4 Ambon sekarang; satu buah "Kweekschool" (sekolah pendidikan guru) dan "STOVIL" (sekolah guru agama Kristen ) yang terletak di Batu Gantong.

Selain itu, pihak swasta di Ambon mendirikan tidak kurang dari delapan buah sekolah, yaitu empat buah HIS

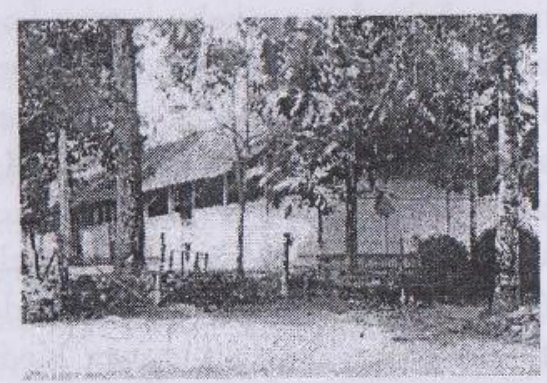

Gedung MULO, terletak JI. Setia Budi, sekaran tepatnya di Kompleks SMP Negeri 4 Ambon yang bernuansa Islam, yaitu dua buah "Asrabische School" (untuk masyarakat Arab). Selain itu masyarakat Cina di kota Ambon juga mendirikan sekolahnya sendiri, "Chineseschool"; kemudian masih ada sebuah sekolah peralihan, yaitu "Schakelscool", yang memungkinkan murid dari sekolah-sekolah swasta untuk pindah ke sekolah pemerintah.

\section{Perkantoran}

Pembangunan yang sistematis dari jalan-jalan dan pemukiman dalam Kota Ambon dilakukan sejak tahun 1644, ketika Gubernur Gerard Demmer mengangkat seorang " Rooymeester" untuk mengawasi pembangunan bangunan-bangunan dalam kota. Rooymeester adalah petugas yang menentukan letak dan bentuk rumah, termasuk bentuk pagarnya. Pada saat ini, aturan semacam itu diatur dalam "Izin Mendirikan Bangunan" (IMB). Menjelang paruh kedua abad ke-17, jumlah penduduk makin meningkat. Pembangunan perumahan pun semakin pesat, sehingga seorang Rooymeester tidak cukup untuk mengaturnya. Oleh karena itu, pada tahun 1666 Kota Ambon mulai dibagi dalam empat "Wijk" (semacam rayon). Masing-masing wijk dipimpin seorang Wijkmeester yang bertanggungjawab kepada Rooymeester. Mereka melaksanakan tugas Rooymeester di wilayahnya, kecuali memberi izin mendirikan rumah atau gedung. Pada masa itu, para Wijkmeester selalu dipilih dari kalangan warga kota berkebangsaan Belanda yang terpandang.

Yang menjadi jalan utama di Kota Ambon pada masa itu adalah "Groote Olievanstraat" yang sekarang bernama jalan Pattimura. Pada kiri kanan jalan utama ini terletak rumah dan gedung-gedung utama pemerintah; seperti Gemeente Kantoor, Post Kantoor, Telefoon Kantoor; Rumah Resident Belanda, dan sebagainya. Jalan utama lainnya adalah "Burgerstraat" yang sekarang bernama jalan D. I. Panjaitan.

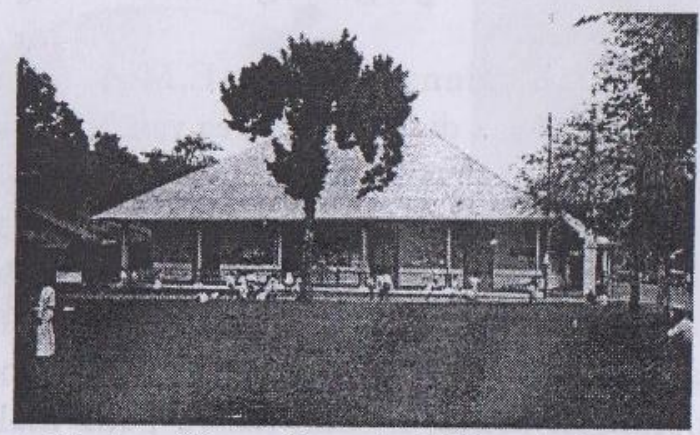

Gemeente Kantoor (Kantor Pemerintah Kota Ambon) tahun 1925 
Di jalan Burgerstraat terdapat sebuah Rumah Sakit yang dibangun oleh Gubernur Arnold de Vlaming van Oudshoorn (1647-1650), tetapi kemudian direnovasi kembali oleh Gubernur N. Schagen (1691-1696) karena telah mengalami kerusakan akibat gempa yang terjadi pada tahun

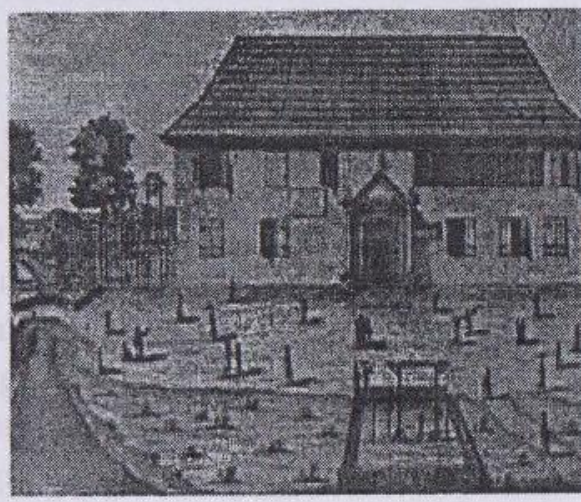

1674. Namun ternyata gedung yang bertingkat dua itu dianggap tidak layak lagi untuk digunakan sebagai rumah sakit. Oleh karena itu, masih di wilayah yang sama, tetapi di seberang Wai Tomo, kemudian dibangun rumah sakit baru yang selesai tahun 1694. sejak itu, rumah sakit lamah dijadikan gedung bagi perkantoran yang berkaitan dengan peradilan. Pada lantai kedua bangunan itu, ditempatkan "Raad van Justitia" (pengadilan untuk pegawai VOC dan warga kota). Di lantai dua itu pula terdapat kantor dari "Weeskamer" (balai peninggalan harta) dan "Commissarissen der Huwelijkzaken" (kantor urusan pernikahan). Di depan gedung itu terdapat sebuah lapangan terbuka dengan tiang gantungan bagi para penjahat yang dijatuhi hukuman mati. Letak tiang gantungan tersebut tepatnya di kawasan Tugu Pahlawan Nasional Thomas Matulessy (Kapitan Pattimura). Kemudian pada abad ke-18, gedung itu diberi nama "Stadhuis" (balaikota), tetapi mulai abad ke-19 dikenal sebagai gedung "Landraad" (pengadilan untuk penduduk negeri).

Gedung pemerintah lainnya adalah E.M.A (Electrische Maatschapij Ambon), yang terletak di jalan "de Weg van Nusaniwe" yang kini dikenal dengan jalan A.M. Sangaji. Adalah sebuah perusahaan swasta (Perusahaan Listrik Ambon) yang berfungsi untuk menyediakan penerangan bagi rumah dan jalan di kota Ambon pada saat itu. Pada tahun 1928, "Gemeenteraad" mengharuskan perrerintah membuat kontrak dengan EMA, dan mulai tahun 1929 rumah-rumah di kota Ambon sudah bisa menikmati penerangan listrik, namun hanya pada malam hari. Disebelah kawasan itu juga, tepatnya di kompleks pelabuhan Ambon,

terdapat KPM Kantoor (Koninklijke Paketvaart Maatschappij), dimana fungsi dan statusnya sama dengan PELNI sekarang.

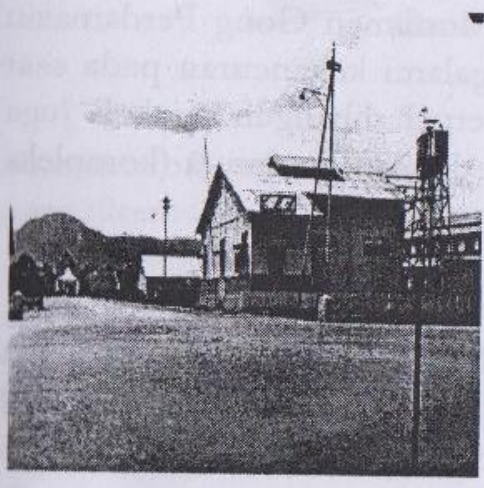

EMA tahun 1935

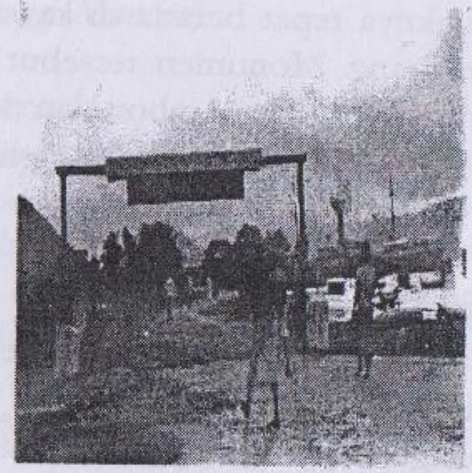

KPM tahun 1900

Terdapat juga "Leprozerie" (tempat tinggal khusus atau tempat perawatan bagi penderita penyakit lepra) dan kilang minyak dari BPM (Bataafse Petroleum Maatschappij) yang terletak di Benteng. Selain itu juga terdapat sebuah rumah sakit pemerintah yang dibangun pada awal abad ke-19, terletak di jalan Dr. Tamaela, kini tepatnya berada di Rumah Sakit Tentara.

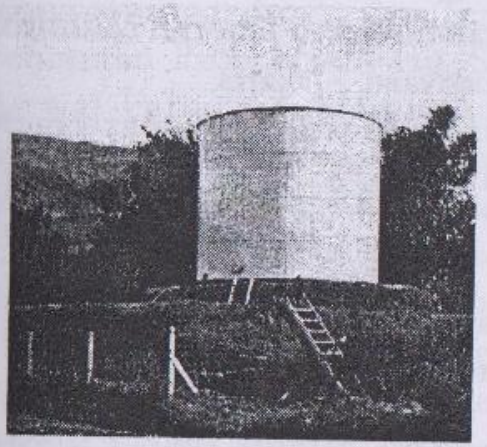

BPM Tahun 1905

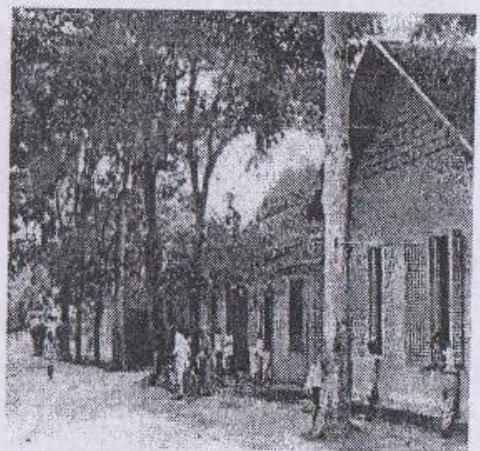

Rumah Sakit Tahun 1925 


\section{Monumen}

Selain gedung-gedung tersebut diatas, Kota Ambon juga didapati memiliki monumen megah yang dulunya menjadi salah satu "icon" kota Ambon yang bernama Monumen Door de eeuwen trouw (berjuang sampai akhir), letaknya tepat berada di kawasan Monumen Gong Perdamaian Dunia sekarang. Monumen tersebut mengalami kehancuran pada saat Jepang membom Kota Ambon dan tidak pernah dibangun kembali. Juga terdapat Monumen Rumphius yang berada di jalan Pattimura (kompleks sekolah katolik).

\section{Penutup}

Berdasarkan data yang ada, memperlihatkan sejarah perkembangan kota yang sangat lekat mencitrakan jejak-jejak pengaruh kota Kolonial yang dibangun oleh Portugis dan Belanda. Meskipun saat ini minim sekali jejak-jejak monumentalnya yang dapat dijumpai namun sejarah membuktikan bahwa sejak embrio kota hingga puncak-puncak perkembangannya, Kota Ambon hadir bersamaan dengan kehadiran kolonial di wilayah ini.

\section{DAFTAR PUSTAKA}

Leirissa R. Z (et.al), 2004 Ambonku, Doeloe, Kini, Esok, Pemerintah Kota Ambon, Ambon

Leirissa R. Z, Pattikayhatu J. A, 1984 Sejarah Sosial di Daerah Maluku, Departemen Pendidikan dan Kebudayaan, Jakarta

Pattikayhatu J. A, 1993 Sejarah Daerah Maluku, Departemen Pendidikan dan Kebudayaan, Ambon, 1993.

\section{Arsip dan Sumber-sumber lain}

- Staatsblad No. 91 tahun 1888.

- KITLV (Koninklijke Instituut voor Taal, Land en Volkenkunde)

- Moluksche Historische Museum - Ultrecht

Pacific Wreck

Perpustakaan Keuskupan Amboina - Ambon

Perpustakaan Siwalima - Ambon

*Penulis, Kandidat Peneliti Balai Arkeologi Ambon 